\section{BOLESŁAW DOMAŃSKI}

Uniwersytet Jagielloński, Kraków

\title{
Polski przemysł na tle przemysłu Europy Środkowej i Wschodniej
}

Przemysł jest tą dziedziną polskiej gospodarki, którą szok transformacji gospodarczej po 1989 roku dotknął w szczególnie głęboki sposób. Priorytetowa rola tego działu w okresie wcześniejszym, widoczna m.in. w jego uprzywilejowaniu w nakładach inwestycyjnych oraz przewaga dużych zakładów i kapitałochłonność produkcji, uczyniły go mniej podatnym na dostosowanie się do nowych warunków gospodarki rynkowej. Znajduje to wyraz w generalnie wolniejszym rozwoju przemysłu niż wielu usług w Polsce i w innych krajach Europy Środkowej i Wschodniej, co nie jest jednak równoznaczne z mniejszą skalą zmian. Warto w tej sytuacji przyjrzeć się przemianom przemysłu Polski w ostatnich kilkunastu latach na tle analogicznych zmian w innych krajach postsocjalistycznych. Jest to szczególnie uzasadnione wobec faktu, że wokół rozwoju polskiego przemysłu w ostatnich latach narosło wiele mitów.

Celem niniejszego opracowania jest porównanie procesu rozwoju oraz współczesnych cech przemysłu Polski ze zmianami i cechami przemysłu innych krajów Europy Środkowej i Wschodniej. W pierwszej części analizowane są tendencje zmian w wielkości produkcji przemysłowej od 1989 do 2001 roku i dyskutowane czynniki warunkujące owe zmiany. Następnie rozważane są kolejno cechy strukturalne i jakościowe, takie jak struktura branżowa, wydajność pracy oraz zdolności eksportowe przemysłu. Bliższą uwagę poświęcono inwestycjom zagranicznym. Dane statystyczne, na których oparta jest analiza, pochodzą z publikacji OECD, Banku Światowego, Eurostatu, Wiener Institut für Internationale Wirtschaftsvergleiche oraz statystyk poszczególnych krajów. Odrębnym, pominiętym w niniejszym artykule zagadnieniem jest regionalne i lokalne zróżnicowanie procesów zmian przemysłu Polski.

\section{WZROST I SPADEK WARTOŚCI PRODUKCJI PRZEMYSŁOWEJ}

Porównanie zmian wartości produkcji przemysłowej krajów Europy Środkowej i Wschodniej od 1989 roku pokazuje, że wyodrębnić można w tym okresie dwie podstawowe fazy rozwoju: fazę szoku, w której nastąpił spadek produkcji, oraz następującą po niej fazę stabilizacji lub wzrostu. U podłoża obniżenia produkcji w fazie szoku leżały przede wszystkim trudności w przystosowaniu się przedsiębiorstw funkcjonujących przez lata w systemie dominacji sprzedawcy, miękkich ograniczeń budżetowych i braku autonomii 
firm, do sytuacji ograniczeń popytowych, gdzie podstawą jest szukanie odbiorców i dostosowanie się do ich wymagań (Żukowski 1993; Kornai 1997). Towarzyszyło temu pojawienie się na krajowym rynku konkurencji ze strony masowo napływających dóbr z importu, nieznanej wcześniej ze względu na odizolowanie gospodarki socjalistycznej od świata, oraz utrata tradycyjnych rynków eksportowych po załamaniu się pozarynkowych rozliczeń międzynarodowych w ramach RWPG. Sytuację makroekonomiczną w niektórych krajach, np. w Polsce, charakteryzowała hiperinflacja i ogromne zadłużenie zagraniczne. Zakorzenienie instytucji i mechanizmów rynkowych, postępująca adaptacja przedsiębiorstw i pojawianie się nowych firm prowadziły do zahamowania spadku produkcji, a następnie jej wzrostu.

Głębokość i długotrwałość okresu załamania produkcji przemysłowej była różna w poszczególnych krajach. Jeszcze większe były różnice w zachowaniu przemysłu różnych krajów w fazie stabilizacji/wzrostu (ryc. 1). Zróżnicowanie to pozwala wyodrębnić trzy grupy krajów.

Zdecydowanie wyróżniają się Węgry i Polska, jedyne kraje postsocjalistyczne, w których produkcja przemysłowa w 2001 roku przekraczała poziom z roku 1989 - odpowiednio o $41 \%$ i $30 \%$. Co więcej osiagnięty w tym okresie wzrost produkcji był wyraźnie szybszy od analogicznego wzrostu w krajach Unii Europejskiej (22\%). W Polsce w ciągu dwóch lat do 1991 roku produkcja przemysłowa obniżyła się o 30\% i od tego czasu aż do 2000 roku wykazywała bardzo szybki wzrost średnio o 9,3\% rocznie. Po dwóch latach spowolnienia 2001-2002, w 2003 roku ponownie wzrosła o 8,7\%. Na Węgrzech wzrost zaczął się o rok później, ale od 1998 roku jego tempo było wyższe niż w Polsce, co pozwoliło na osiagnięcie lepszych wskaźników w całym analizowanym okresie. Jedynym krajem europejskim, który wykazywał w tym czasie szybszy wzrost produkcji przemysłowej, była Irlandia.

Odrębną grupę krajów stanowią Słowacja, Czechy i Słowenia. Dwa ostatnie są najwyżej rozwiniętymi krajami regionu. Najniższy poziom produkcji w porównaniu z 1989 rokiem był w tych krajach podobny jak na Węgrzech (spadek o 1/3), przypadł jednak nieco później (1993). Od tego momentu obserwujemy w nich wzrost produkcji, jego tempo wyraźnie ustępowało jednak dynamice przemysłu polskiego i węgierskiego i nie pozwoliło osiągnąć poziomu z 1989 roku.

W pozostałych krajach postsocjalistycznych załamanie produkcji było znacznie głębsze i trwało do drugiej połowy lat 90 . Pomimo wzrostu w ostatnich latach wartość produkcji przemysłowej jest tu obecnie w porównaniu z 1989 rokiem wciąż niższa o 30-40\% (Estonia, Ukraina, Rosja, Chorwacja), a nawet o około 50\% lub więcej (Rumunia, Bułgaria, Litwa, Łotwa, większość krajów bałkańskich). Warto zauważyć, że do grupy tej zaliczyć można również dawną NRD, gdzie w latach 1989-92 produkcja spadła o prawie 2/3, a dziś kształtuje się $40 \%$ poniżej poziomu sprzed włączenia do RFN.

Warto zastanowić się nad czynnikami, które wpłynęły na tak zróżnicowane zachowanie przemysłu krajów postsocjalistycznych. Jak nietrudno zauważyć, spadek produkcji został zahamowany najszybciej i zastąpiony przez jej wzrost tam, gdzie mechanizmy rynkowe wprowadzono najwcześniej, w sposób szybki i całościowy, a więc w dwóch pierwszych grupach krajów. Niewątpliwie ogromny wpływ miało tempo przekształceń własnościowych - prywatyzacji przedsiębiorstw państwowych i rozwoju nowych firm produkcyjnych. Podmioty prywatne okazały się dużo bardziej skuteczne w znajdowaniu nowych rynków oraz osiąganiu wyższej wydajności pracy i lepszej jakości wyrobów (Frydman, Rapaczyński 1995). Trudno pominąć tu znaczenie kulturowo zakorzenionej przedsiębiorczości, której przejawy widoczne były w Polsce i na Węgrzech w postaci indywidualnej aktywności społecznej i gospodarczej na długo przed rokiem 1989. Istotne mogły być również wcześniejsze intensywne kontakty osobiste z zagranicą związane $\mathrm{z}$ dawną emigracją oraz wyjazdami 
zarobkowymi, sprzyjające przenikaniu wzorców kulturowych oraz późniejszym kontaktom handlowym. Atutem Polski był również zdecydowanie największy rynek wewnętrzny wśród krajów, które wcześnie weszły na drogę reform, co ułatwiało rozwój rodzimych firm, stanowiło także o atrakcyjności kraju dla inwestorów z zagranicy. W rezultacie wzrost produkcji przemysłowej w Polsce napędzany był zarówno przez rosnącą konsumpcję w kraju (dochody realne rosły od 1991 roku - zob. Bywalec 1998), substytucję importu, jak i szybko zwiększający się eksport na rynki Europy Zachodniej. Kapitał zagraniczny odegrał największą rolę w prywatyzacji przemysłu węgierskiego. Przypadek byłej NRD pokazuje, że sama wielkość dostępnego kapitału nie była jednak głównym czynnikiem sukcesu. Elementarnym warunkiem wzrostu produkcji była generalna stabilność i przewidywalność sytuacji politycznej. Wpływ czynników politycznych widoczny jest także w postaci trudności wynikających z podziału ZSRR, Czechosłowacji i Jugosławii oraz działań wojennych na terytorium tej ostatniej.

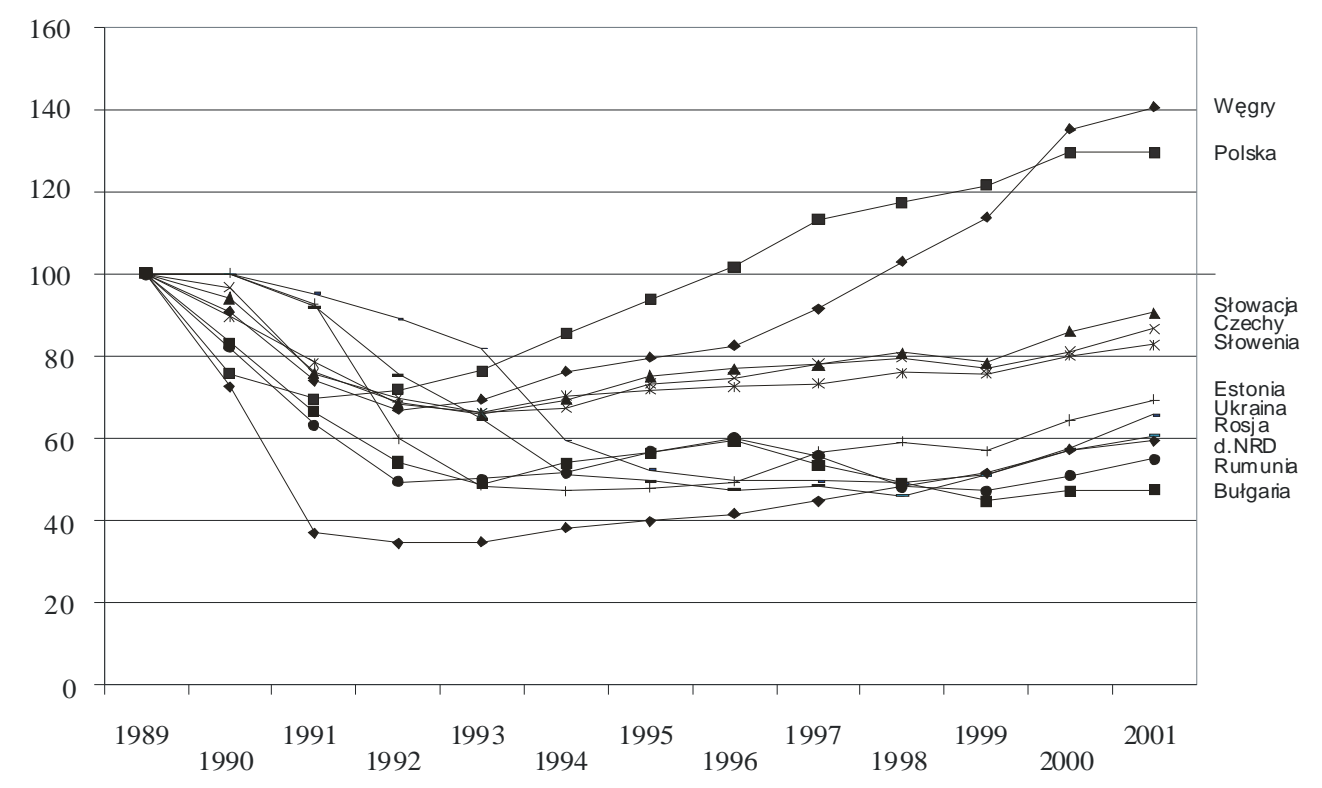

Ryc. 1. Dynamika wartości produkcji przemysłowej wybranych krajów postsocjalistycznych w latach 1989-2001 $(1989=100)$

Źródło: opracowanie własne na podstawie Economic Survey of Europe, 2002, No. 1

W sumie powyższa analiza pokazuje, że wbrew rozpowszechnionym opiniom o upadku polskiego przemysłu, kształtowanym m.in. przez nagłaśniane w mediach trudności i upadłości wielkich znanych zakładów, przemysł ten należał w kategoriach wielkości produkcji do najszybciej rozwijających się nie tylko wśród krajów postsocjalistycznych, ale także w skali całej Europy. Jeszcze większe znaczenie mają zachodzące równolegle zmiany strukturalne i jakościowe. 


\section{ZMIANY STRUKTURY BRANŻOWEJ}

Zmiany wielkości produkcji w poszczególnych działach przemysłu Polski były bardzo zróżnicowane, co oznacza, że zachodziły istotne przekształcenia struktury branżowej. Na tle krajów wyżej rozwiniętych dziedzictwem socjalistycznej polityki gospodarczej były rozbudowane zdolności wydobycia surowców mineralnych oraz produkcji energii, prostych pół-

Tabela 1. Dynamika przemysłu Polski według sekcji i działów w latach 1992-2000 (1992 = 100)

\begin{tabular}{|c|c|c|c|c|}
\hline PKD & Dział & $\begin{array}{c}\text { Dynamika } \\
\text { wartości dodanej }\end{array}$ & $\begin{array}{c}\text { Dynamika } \\
\text { liczby pracujących }\end{array}$ & $\begin{array}{c}\text { Dynamika } \\
\text { wydajności pracy }^{1}\end{array}$ \\
\hline 15 & artykuły spożywcze i napoje & 204 & 100 & 204 \\
\hline 16 & wyroby tytoniowe & 73 & 74 & 99 \\
\hline 17 & włókiennictwo & 107 & 52 & 206 \\
\hline 18 & odzież i wyroby futrzarskie & 156 & 85 & 184 \\
\hline 19 & skóry i wyroby ze skóry & 84 & 54 & 156 \\
\hline 20 & drewno i wyroby $\mathrm{z}$ drewna & 182 & 108 & 169 \\
\hline 21 & masa włóknista i papier & 268 & 106 & 253 \\
\hline 22 & $\begin{array}{l}\text { działalność wydawnicza } \\
\text { i poligrafia }\end{array}$ & 406 & 126 & 322 \\
\hline 23 & $\begin{array}{l}\text { koks i produkty rafinacji ropy } \\
\text { naftowej }\end{array}$ & 82 & 78 & 105 \\
\hline 24 & wyroby chemiczne & 158 & 77 & 205 \\
\hline 25 & wyroby gumowe i z tworzyw szt. & 406 & 138 & 294 \\
\hline 26 & $\begin{array}{l}\text { wyroby z surowców niemeta- } \\
\text { licznych }\end{array}$ & 259 & 89 & 291 \\
\hline 27 & metale & 131 & 59 & 222 \\
\hline 28 & wyroby z metali & 259 & 112 & 231 \\
\hline 29 & maszyny i urządzenia & 191 & 67 & 285 \\
\hline 30 & maszyny biurowe i komputery & 1633 & 95 & 1719 \\
\hline 31 & maszyny i aparatura elektryczna & 271 & 102 & 266 \\
\hline 32 & $\begin{array}{l}\text { sprzęt telewizyjny i telekomu- } \\
\text { nikacyjne }\end{array}$ & 447 & 55 & 813 \\
\hline 33 & $\begin{array}{l}\text { instrumenty medyczne } \\
\text { i precyzyjne }\end{array}$ & 327 & 88 & 372 \\
\hline 34 & pojazdy mechaniczne & 280 & 87 & 322 \\
\hline 35 & pozostały sprzęt transportowy & 131 & 67 & 196 \\
\hline 36 & meble i pozostała produkcja & 226 & 112 & 202 \\
\hline 37 & zagospodarowanie odpadów & 174 & 129 & 135 \\
\hline D & przetwórstwo przemysłowe & 211 & 87 & 242 \\
\hline $\mathbf{C}$ & górnictwo i kopalnictwo & 83 & 49 & 169 \\
\hline \multirow[t]{2}{*}{$\mathbf{E}$} & zaopatrywanie w energie & 127 & 93 & 137 \\
\hline & Przemysł ogółem & 180 & 83 & 217 \\
\hline
\end{tabular}

${ }^{1}$ wartość dodana na 1 pracującego

Źródło: opracowanie własne na podstawie danych GUS 
produktów (np. stali, podstawowych chemikaliów), ciężkich maszyn i uzbrojenia, przy niedorozwoju wytwarzania wyrobów bardziej złożonych i konsumpcyjnych (Paszkowski 1996). Powrót do gospodarki rynkowej zaowocował dramatycznym spadkiem wydobycia węgla kamiennego i siarki, a w efekcie zmniejszeniem produkcji przemysłu wydobywczego o około połowę, pomimo że np. wydobycie rud miedzi i węgla brunatnego nie uległo istotnym zmianom. Rozwój tradycyjnych branż przemysłu przetwórczego oraz branż odgrywających priorytetową rolę w epoce socjalizmu był po 1989 roku zdecydowanie wolniejszy od rozwoju całego przemysłu (np. koksowniczy i rafineryjny, pozostałe środki transportu) lub nastąpił w nich spadek produkcji (hutnictwo stali, włókienniczy, skórzany, tytoniowy). Najszybszy, ponadtrzykrotny wzrost miał miejsce w wytwarzaniu komputerów, wyrobów z gumy i tworzyw sztucznych, elektrycznych, precyzyjnych, sprzętu telewizyjnego i telekomunikacyjnego oraz $\mathrm{w}$ wydawnictwach i poligrafii, niewiele wolniejszy w zakresie produkcji samochodowej, papierniczej, wyrobów z surowców niemetalicznych oraz wyrobów z metalu (tab. 1). Tendencje te wskazują na proces stopniowego upodabniania struktury polskiego przemysłu do struktury przemysłu krajów wysoko rozwiniętych, poprzez rosnący udział wyrobów średniozaawansowanych technologicznie oraz podstawowych wyrobów konsumpcyjnych kosztem produktów dominujących w okresie socjalizmu. Udział przemysłów wysokiej techniki jest w porównaniu z Europą Zachodnią niski, chociaż wykazywały one po 1989 roku bardzo szybkie tempo wzrostu. Nie należy zapominać, że zmianom struktury branżowej towarzyszyły w tym okresie istotne zmiany w strukturze wielkościowej przedsiębiorstw - rosnący udział małych i średnich podmiotów produkcyjnych.

\section{WYDAJNOŚĆ PRACY I TECHNOLOGIA}

Spojrzenie na przemysł Polski z punktu widzenia zmian wielkości zatrudnienia daje obraz całkowicie odmienny od tego, jaki wynika ze wzrostu produkcji. Liczba pracujących w przemyśle kraju była w 2001 roku o prawie $40 \%$ mniejsza niż 12 lat wcześniej. Znaczny spadek zatrudnienia wystąpił we wszystkich krajach Europy Środkowej i Wschodniej.

Można wyróżnić dwie zasadnicze grupy przyczyn spadku zatrudnienia: ograniczenie produkcji lub obniżenie pracochłonności związane ze zmianami $\mathrm{w}$ technologii i organizacji produkcji. W Polsce w większości branż i przedsiębiorstw decydujące znaczenie miała ta druga grupa przyczyn. Nastąpił w nich znaczący postęp technologiczny, największy w branżach i zakładach zorientowanych eksportowo i należących do dużych korporacji zagranicznych. Przemysłami, które dokonały olbrzymiego skoku technologicznego, są między innymi poligraficzny, meblarski, samochodowy, elektroniczny oraz liczne dziedziny spożywczego. Całkowita wymiana linii technologicznych nastąpiła w fabrykach sprzętu telekomunikacyjnego, czołowi producenci przetworów mięsnych, owocowo-warzywnych i mleczarskich osiągnęli standard dorównujący wytwórniom w Unii Europejskiej. Towarzyszyły temu głębokie zmiany w organizacji i zarządzaniu.

Porównanie dynamiki wartości produkcji i wielkości zatrudnienia (ryc. 2) pozwala uchwycić zmiany w zakresie wydajności pracy w przemyśle poszczególnych krajów. Rosnąca produkcja przy malejącym zatrudnieniu oznacza, że ponaddwukrotny wzrost wydajności pracy nastąpił $\mathrm{w}$ przemyśle polskim i węgierskim. W samym przemyśle przetwórczym wzrost wydajności w obu krajach był jeszcze szybszy. Skala zmian wydajności pracy 
w przemyśle pozostałych krajów była zdecydowanie mniejsza: w Słowenii i Czechach zwiększyła się ona w latach 1989-2001 o 20-25\%, czyli mniej niż w wielu krajach Unii Europejskiej. Kilkunastoprocentowy wzrost miał miejsce w Rumunii i na Ukrainie, w Rosji wydajność pracy uległa według oficjalnych danych obniżeniu.

Istotne znaczenie z punktu widzenia efektywności ekonomicznej ma relacja dynamiki wydajności pracy i płac realnych w przemyśle. Nieporównywalność danych GUS sprzed 1992 roku i z okresu późniejszego utrudnia precyzyjne porównania dla poszczególnych branż dla całego okresu 1989-2001. W latach 1992-2000 średni wzrost płac realnych w przemyśle przetwórczym wyniósł $35 \%$, podczas gdy wydajność pracy zwiększyła się w tym samym czasie o $142 \%$, tj. prawie dwuipółkrotnie. Ponadtrzykrotny wzrost wydajności nastąpił w branżach zaawansowanych technologicznie: komputerowej, sprzętu telewizyjnego i telekomunikacyjnego, precyzyjnej, samochodowej oraz poligrafii. Ponadprzeciętne zwiększenie wydajności miało ponadto miejsce $\mathrm{w}$ produkcji wyrobów elektrycznych, z gumy i tworzyw sztucznych, z surowców niemetalicznych, maszyn oraz papieru i wyrobów z papieru. $\mathrm{Z}$ branż tradycyjnych, w których wzrost produkcji był niewielki lub zanotowano jej spadek, wydajność wzrosła znacząco w hutnictwie metali i przemyśle włókienniczym (ponaddwukrotnie), a także skórzanym i wytwarzaniu pozostałych środków transportu.

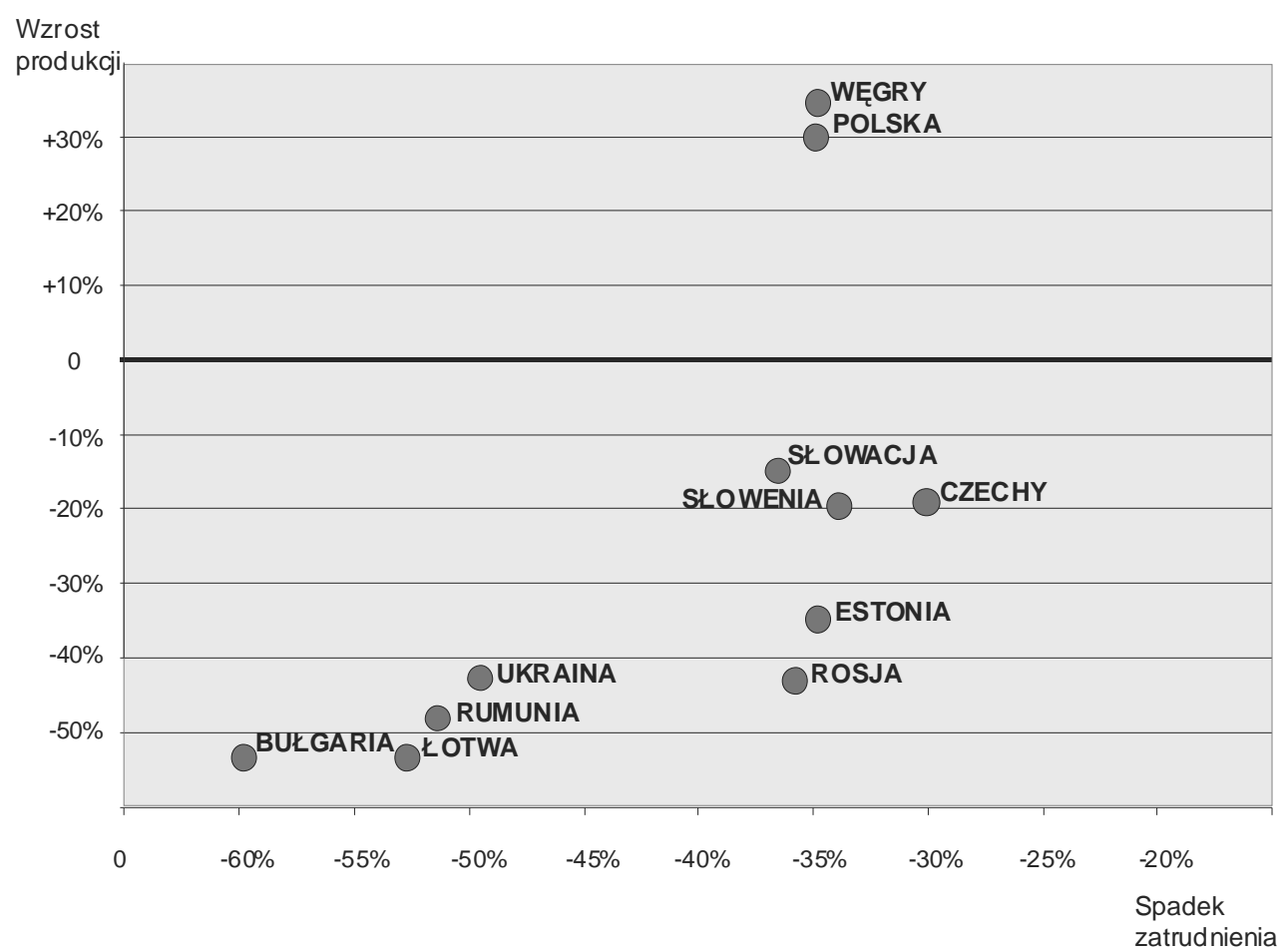

Ryc. 2. Zmiany wartości produkcji i wielkości zatrudnienia w przemyśle wybranych krajów postsocjalistycznych w latach 1989-2001 Źródło: opracowanie własne na podstawie Economic Survey of Europe, 2002, No. 1 
EKSPORT WYROBÓW PRZEMYSŁOWYCH

Rosnące zdolności eksportowe polskich firm przemysłowych były, jak podkreślano, jednym z ważnych czynników szybkiego wzrostu produkcji po 1991 roku. Towarzyszyła temu radykalna zmiana kierunków eksportu. W bardzo krótkim czasie dominacja ZSRR i innych krajów RWPG zastąpiona została eksportem na rynki krajów wysoko rozwiniętych, przede wszystkim zachodnioeuropejskich. Udział 15 krajów Unii Europejskiej przekroczył $70 \%$, w tym na same Niemcy przypada około $1 / 3$ całego eksportu.

Dynamiczny wzrost eksportu do krajów wysoko rozwiniętych jest dobitnym potwierdzeniem pozytywnych zmian jakościowych i strukturalnych w polskim przemyśle. Wartość polskiego eksportu do Unii Europejskiej zwiększyła się między 1989 a 2002 rokiem około sześciokrotnie, w tym eksportu maszyn, urządzeń i środków transportu blisko dwudziestokrotnie. Ta ostatnia grupa wyrobów stanowi dziś $38 \%$ wartości polskiego eksportu do krajów UE w porównaniu do zaledwie 12\% w 1989 r. Udział surowców, paliw i żywności zmalał z 40 do $14 \%$. Pozostała część eksportu przypada na inne wyroby przemysłu przetwórczego.

Porównanie z innymi krajami postsocjalistycznymi pokazuje, że większy eksport wyrobów przemysłowych do krajów UE na 1 mieszkańca oraz wyższy udział maszyn, urządzeń i środków transportu w owym eksporcie charakteryzują Czechy i Węgry (odpowiednio $47 \%$ i 57\% udział ww. grupy wyrobów). W przypadku Słowenii i Słowacji udział maszyn i środków transportu w eksporcie jest podobny jak w Polsce przy wyższej wartości eksportu na 1 mieszkańca. Bardzo wyraźny jest kontrast między wszystkimi tymi krajami a Rumunia, Bułgarią, Rosją i Ukrainą, gdzie maszyny, urządzenia i środki transportu stanowią co najwyżej kilkanaście procent całości eksportu, a w eksporcie do UE odsetek ten jest jeszcze dużo niższy.

Warto w tym miejscu zauważyć, że systematycznie rosnący eksport wyrobów przemysłowych z postsocjalistycznych krajów Europy Środkowej do Niemiec przewyższa już analogiczny eksport z kolebki rewolucji przemysłowej Wielkiej Brytanii. W 2001 roku wyroby pochodzące z tego kraju stanowiły $6,9 \%$ wartości niemieckiego importu, podczas gdy łączna wartość importu z Polski, Czech i Węgier przekroczyła 7,4\% i różnica na korzyść rosnącej roli tych trzech ostatnich krajów z roku na rok się powiększa. Liczba mieszkańców trzech wymienionych krajów jest prawie identyczna jak liczba mieszkańców Wielkiej Brytanii (59 milionów), przy kilkakrotnie niższym produkcie krajowym brutto. Od kilku lat bilans wymiany handlowej między Polską a jej głównym partnerem handlowym Niemcami jest zrównoważony, ujemne saldo wymiany z całą Unią Europejską jest z roku na rok mniejsze.

Najważniejsze branże eksportowe polskiego przemysłu stanowią produkcja samochodów i ich części, wyrobów elektronicznych, elektrycznych, pozostałych środków transportu (statków), mebli oraz odzieży. Rośnie eksport wyrobów z gumy i tworzyw sztucznych, papieru oraz metalu. Około połowa eksportu przypada w Polsce na firmy z kapitałem zagranicznym. 


\section{INWESTYCJE ZAGRANICZNE}

Jednym z istotnych, chociaż nie decydujących czynników, które różnicowały kraje Europy Środkowej i Wschodniej, były bezpośrednie inwestycje zagraniczne. Polska była krajem, który w latach 1989-2001 przyciągnął bezwzględnie największy kapitał z zagranicy - 57 mld USD (według PAIZ). O około połowę mniejsze były inwestycje w Rosji, Czechach i na Węgrzech - od 24 do 28 mld USD (według MFW). W przeliczeniu na 1 mieszkańca większe nakłady niż w Polsce miały miejsce w Czechach, na Węgrzech, w Słowenii oraz Estonii. Na przemysł przypadało w większości krajów od 40 do 55\% inwestycji (Gradev 2001).

Branżami przemysłu polskiego, w których obserwujemy największe zaangażowanie zagranicznego kapitału, są produkcja artykułów spożywczych i napojów, samochodów oraz wyrobów z surowców niemetalicznych, a w dalszej kolejności chemikaliów i wyrobów chemicznych, papieru i wyrobów z papieru, wyrobów tytoniowych oraz z gumy i tworzyw sztucznych. Nawiązując do trzech typów przemysłów będących, zdaniem P. Dickena (1998), przedmiotem głównego zainteresowania korporacji ponadnarodowych, możemy stwierdzić, że w przypadku Polski jest to przede wszystkim wielkoskalowa produkcja markowych dóbr konsumpcyjnych (np. papierosów, napojów, żywności, kosmetyków) - ponad 30\% kapitału, oraz średnio zaawansowanych technologicznie dóbr trwałego użytku (np. samochodów, telewizorów) - 23\%. $\mathrm{Na}$ wąsko rozumiane przemysły wysokiej techniki przypada 6-7\% inwestycji (Domański 2001). Duże nakłady mają poza tym miejsce w produkcji wyrobów o standardowej technologii: materiałów budowlanych, szkła, papieru i chemikaliów.

Zagraniczne inwestycje zwiększają konkurencyjność przedsiębiorstw poprzez wprowadzanie lepszych technologii i organizacji produkcji oraz wzrost efektywności. Wyższa jakość produktów i uzyskanie za pośrednictwem inwestorów dostępu do rynków krajów wysoko rozwiniętych sprawiaja, że rośnie eksport wyrobów przemysłowych. Produkcja firm zagranicznych na rynek krajowy ma w niemałym stopniu charakter substytucji importu, firmy te generują jednak również duży import. Efektem modernizacji technologicznej jest m.in. ograniczenie negatywnego oddziaływania fabryk na środowisko. Generalny pozytywny wpływ zagranicznych inwestorów na proces modernizacji przemysłu w Polsce jest niewątpliwy, chociaż poziom wprowadzanych technologii jest zróżnicowany, zdarza się przenoszenie linii technologicznych z Europy Zachodniej. Przeważają technologie opracowane za granica, co oznacza ograniczone wykorzystanie lokalnej działalności badawczo-rozwojowej.

Korzystny wpływ inwestorów na rynek pracy dotyczy bardziej cech jakościowych (kwalifikacje kadry, warunki pracy, wynagrodzenia) niż ilościowych. Nowe miejsca pracy powstają przede wszystkim dzięki budowie nowych fabryk. Zamykanie zakładów należących do firm z udziałem zagranicznym było jak dotąd zjawiskiem rzadkim i wynikało głównie z przenoszenia lub koncentracji produkcji inwestora w innych zakładach w Polsce, a nie relokacji do innych krajów. Siła powiązań zaopatrzeniowych z krajowymi dostawcami jest zróżnicowana między branżami i firmami. Integracja z gospodarką światową za pośrednictwem inwestorów zagranicznych oznacza równocześnie silniejsze uzależnienie od trendów globalnych, zagranicznych technologii oraz decyzji podejmowanych za granicą (Domański 2003).

Akcentując rolę inwestorów zagranicznych, nie należy zapominać, że wzrost produkcji przemysłowej w Polsce był w jeszcze większym stopniu wynikiem działalności przedsiębiorstw z kapitałem rodzimym. Rozwijały się zarówno liczne małe i średnie firmy, jak i duże przedsiębiorstwa sprywatyzowane i założone po 1989 roku. Przykładami nowych firm, które stały się liderami w swojej branży, mogą być Atlas, Tele-Fonika, Maspex czy Black Red White. Niektóre z nich stały się dużymi eksporterami, np. Inter Groclin, Amica. 
WNIOSKI

Dynamika wzrostu i jakościowe zmiany, jakie nastapiły w polskim przemyśle po 1989 roku, przybliżają go do standardów i struktur przemysłu krajów Unii Europejskiej. Większa konkurencyjność wyraża się w wyższej wydajności pracy, lepszej jakości wyrobów i rosnących zdolnościach eksportowych. Wiąże się to z postępem w organizacji i zarządzaniu, technologii i standardach ekologicznych, a także z wyższymi kwalifikacjami kadry. Negatywnym efektem zachodzących zmian jest malejąca liczba miejsc pracy w przemyśle, wpływająca na wzrost bezrobocia w wielu miastach i regionach.

W porównaniu z przemysłem innych krajów Europy Środkowej i Wschodniej Polska jako jedyna obok Węgier osiagnę̧ła $\mathrm{w}$ okresie postsocjalistycznej transformacji szybki wzrost produkcji przemysłowej. Również tempo zmian jakościowych, np. wzrostu wydajności pracy oraz dynamiki i korzystnych zmian struktury eksportu, ustępowało tylko analogicznym zmianom na Wegrzech. Zmniejszeniu uległ w tym zakresie dystans w stosunku do przemysłu Czech i Słowenii, pogłębiała się natomiast systematycznie przewaga nad wschodnimi sąsiadami Polski oraz krajami bałkańskimi.

U podłoża wzrostu produkcji i pozytywnych przemian przemysłu Polski leżało szybkie wprowadzenie reform rynkowych, dynamika podmiotów prywatnych, kultura przedsiębiorczości, powiązania zagraniczne, napływ kapitału zagranicznego, duży rynek wewnętrzny i jego wzrost oraz względna stabilność polityczna. Warto zwrócić uwagę na duże znaczenie kapitału ludzkiego dla rozwoju firm rodzimych i przyciagania inwestorów zagranicznych. Zdolności adaptacyjne kadry i stosunkowo dobry ogólny poziom wykształcenia w połączeniu ze specyficznymi kwalifikacjami menedżerskimi lub technicznymi w poszczególnych firmach pozwalają na osiaganie standardów jakościowych wyrobów nieodbiegających od wymogów zachodnioeuropejskich, a także na szybki wzrost wydajności pracy. Zachodzi to przy płacach, które pomimo realnego wzrostu od 1991 roku, pozostają relatywnie niskie w porównaniu z Europą Zachodnią, oraz generalnie mało konfliktowych relacjach ze związkami zawodowymi w większości firm prywatnych.

Zmiany zachodzące $\mathrm{w}$ przemyśle całego kraju, a także poszczególnych regionów, branż oraz przedsiębiorstw rozpatrywać można w kategoriach dwóch typów restrukturyzacji: pasywnej i ofensywnej. Pierwsza z nich oznacza zmiany będące reakcją na postępującą utratę zdolności do konkurowania na rynku i malejącą produkcję, wiąże się więc z deindustrializacją. Restrukturyzacja ofensywna to działania prowadzące do wzrostu rozmiarów, jakości i efektywności produkcji oraz kwalifikacji kadry. Oba rodzaje restrukturyzacji powodować mogą ograniczenie wielkości zatrudnienia, w tym drugim przypadku jest to jednak obniżenie do poziomu, na którym następuje stabilizacja liczby miejsc pracy i zwiększenie ich długoterminowej trwałości.

Przewaga pozytywnych tendencji i zmian jakościowych nie oznacza więc, że przekształcenia polskiego przemysłu były bezproblemowe i przyniosły wyłącznie pozytywne efekty. Wiele firm i zakładów okazało się niezdolnych to dostosowania się do nowych warunków. Dotychczasowy rozwój nie stanowi też gwarancji sukcesu w latach następnych.

Nie należy zapominać, że pod względem zdolności eksportowych i wydajności przemysł Polski wciąż ustępuje przemysłowi Słowenii, Czech i Węgier, a tym bardziej Europy Zachodniej. Niektóre z czynników, jakie napędzały wzrost produkcji w pierwszej dekadzie po zmianie systemu polityczno-gospodarczego, tracą znaczenie, np. wcześniejszy niedoro- 
zwój wielu branż produkcji wyrobów konsumpcyjnych. Polskę charakteryzują sztywne stosunki pracy i związane z tym wyższe koszty pracy w porównaniu do bardziej rozwiniętych Czech i Węgier. Zdolność generowania innowacji jest jak dotąd niewielka, a zależność technologiczna od zagranicy bardzo wyraźna. Są to zagrożenia i wyzwania dla polskiego przemysłu. Przypomnieć można, że tzw. nowoprzemysłowe kraje Azji Wschodniej w pierwszym etapie szybkiego wzrostu również charakteryzowała zależność technologiczna, przezwyciężona jednak w okresie późniejszym.

Długookresowy sukces polskiego przemysłu zależeć będzie od roli, jaką producenci zlokalizowani w Polsce odgrywać będą w europejskim i globalnym podziale pracy, jaki będzie udział produkcji złożonych wyrobów o wysokiej wartości dodanej, opartych na nierutynowych procesach i wysoko kwalifikowanej kadrze. Nie ma wątpliwości, że większość produkcji przemysłowej stanowić będą zakłady wytwarzające standardowe wyroby, podobne do tych powstających w wielu innych krajach. Ważne jest jednak to, czy przybywać będzie w Polsce zakładów - zarówno przedsiębiorstw rodzimych jak i filii firm zagranicznych - pełniących rolę specjalistycznych dostawców zaawansowanych wyrobów na rynki światowe, gdzie produkcji towarzyszyć będą funkcje badawczo-rozwojowe, projektowe i marketingowe. Nie chodzi tu o wąsko rozumiane przemysły wysokiej techniki, ale rozwój tego rodzaju producentów w wielu branżach - zwłaszcza w stosunku do działalności montażowej i wytwarzania prostych, pracochłonnych wyrobów.

\section{Literatura}

Bywalec C., 1998, Społeczne aspekty transformacji gospodarczej w Europie Środkowo-Wschodniej. Kraków: Akademia Ekonomiczna

Dicken P., 1998, Global shift: transforming the world economy. London: Paul Chapman Publishing

Domański B., 2001, Kapitał zagraniczny w przemyśle Polski. Kraków: Instytut Geografii i Gospodarki Przestrzennej Uniwersytetu Jagiellońskiego

Domański B., 2003, Industrial change and foreign direct investment in the postsocialist economy: the case of Poland, European Urban and Regional Studies, 10, 2, 99-118

Frydman R., Rapaczyński A., 1995, Prywatyzacja w Europie Wschodniej. Czy państwo traci na znaczeniu? Kraków: Znak

Gradev G. (red.), 2001, CEE countries in the EU companies' strategies of industrial restructuring and relocation. Brussels: European Trade Union Institute

Kornai J., 1997, Struggle and hope. Essays on stabilization and reform in a post-socialist economy. Cheltenham: Edward Elgar

Paszkowski M., 1996, Zmiany strukturalne przemystu. Metody badania i tendencje światowe a transformacje w krajach Europy Środkowo-Wschodniej. Kraków: Uniwersytet Jagielloński

Żukowski R., 1993, Stabilization and recession in a transitional economy: the case of Poland, World Development, 21, 7, 1163-78 